\title{
Chemical change of leaves during breakdown affects associated invertebrates in a subtropical stream
}

\author{
Mudanças químicas dos detritos foliares durante a decomposição afetam os \\ invertebrados associados em um riacho subtropical
}

\footnotetext{
Alan Mosele Tonin ${ }^{1,2}$, Rozane Maria Restello ${ }^{2}$ and Luiz Ubiratan Hepp ${ }^{2}$

${ }^{1}$ Programa de Pós-Graduação em Ecologia, Departamento de Ecologia, Instituto de Ciências Biológicas, Universidade de Brasília - UnB, Asa Norte, CEP 70910-900, Brasília, DF, Brazil e-mail: tonin.alan@gmail.com

${ }^{2}$ Programa de Pós-Graduação em Ecologia, Departamento de Ciências Biológicas, Universidade Regional Integrada do Alto Uruguai e das Missóes - URI, Av. Sete de Setembro, 1621, CP 743,

CEP 99700-000, Erechim, RS, Brazil

e-mail: rrozane@uri.com.br; luizuhepp@gmail.com
}

\begin{abstract}
Aims: Our objective was assess the effects of leaf chemical change during breakdown on the associated invertebrates. Methods: We evaluate the chemical composition of leaves (of two tree species; Sebastiania brasiliensis and Campomanesia xanthocarpa) and the density of invertebrates during leaf breakdown (on four incubation times; 3, 7, 14 and 22 days) in a subtropical stream. Linear multiple regression analysis were performed to evaluate the relationship between invertebrate density and changes in leaf chemical during breakdown. Results: Density of invertebrates was related to the chemical composition of leaves. There was a positive correlation of $\mathrm{K}(\beta=3.48)$ and a negative of $\mathrm{C}: \mathrm{N}(\beta=-0.34)$, polyphenols $(\beta=-0.16), \mathrm{Ca}(\beta=-2.98)$ and $\mathrm{Mg}$ $(\beta=-2.58)$ with the total density of invertebrates. Density of invertebrates on leaves reached $38 \pm 9$ and $192 \pm 31$ individuals $\mathrm{g}^{-1}$ leaf DM during the first 3 and 7 days of incubation, had decreased by the 14th day $(117 \pm 18)$ and then increased after 22 days $(270 \pm 41)$. Conclusions: We conclude that changes in the chemistry of decomposing leaves affect invertebrate colonization process. This conclusion reinforce the importance of understand the dynamic of energy and nutrients and its association with the biological communities of tropical riparian ecosystems.
\end{abstract}

Keywords: leaf chemistry, chemical composition, litter decomposition, tropical stream, functional feeding group.

Resumo: Objetivos: Nosso objetivo foi avaliar o efeito de mudanças na composição química dos detritos foliares durante a decomposição sobre os invertebrados associados. Métodos: Avaliamos a composição química dos detritos foliares (de duas espécies arbóreas, Sebastiania brasiliensis e Campomanesia xanthocarpa) e a densidade de invertebrados durante a decomposição (em quatro tempos de incubação; 3, 7, 14 e 22 dias) em um riacho subtropical. Realizamos análises de regressão linear múltipla para avaliar a relação entre a densidade de invertebrados e as mudanças na composição química dos detritos foliares durante a decomposição. Resultados: A densidade de invertebrados foi relacionada com a composição química dos detritos foliares. Houve uma correlaçáo positiva de $\mathrm{K}$ ( $\beta=3.48)$ e uma negativa de C:N $(\beta=-0.34)$, polifenóis $(\beta=-0.16)$, Ca $(\beta=-2.98)$ e $\mathrm{Mg}(\beta=-2.58) \mathrm{com}$ a densidade total de invertebrados. A densidade de invertebrados nos detritos foliares alcançou $38 \pm 9$ e $192 \pm 31$ indivíduos por grama de massa seca durante os primeiros três e sete dias de incubação, diminuindo no $14^{\circ}(117 \pm 18)$ e então aumentando no $22^{\circ}$ dia $(270 \pm 41)$. Conclusóes: Concluímos que as mudanças na química dos detritos foliares em decomposição afetam o processo de colonização por invertebrados. Essa conclusão reforça a importância do entendimento da dinâmica de energia e de nutrientes e sua associaçáo com as comunidades biológicas em ecossistemas ripários tropicais.

Palavras-chave: química foliar, composição química, decomposição de detritos, riacho tropical, grupo trófico funcional. 


\section{Introduction}

Leaf litter from riparian trees is fundamental for the functioning of forested headwater streams because it provides the main source of carbon and nutrients for the ecosystem (Wallace, 1997). After reaching a stream, these leaves suffer various physical and chemical processes including an initial rapid leaching phase when water-soluble compounds are lost, bacterial and fungal colonisation, and mechanical breakdown of leaf structure due to water flow and shredder invertebrates (Graça, 2001). The single-effect or interaction of these processes is responsible to chemical change of leaf litter over breakdown that affect invertebrate and microbial communities (Ardón and Pringle, 2008).

The leaching of soluble compounds may account for considerable loss of leaf initial mass and can be responsible for greater reduction of secondary compounds concentration (Gonçalves et al., 2012). Microbial colonization (especially fungi) enhance leaf breakdown by macerating and metabolizing the leaf tissue and indirectly increases the concentration of leaf nutrients (e.g. N and P), increasing the palatability of leaves to invertebrates (Hieber and Gessner, 2002). The fragmentation of leaves occurs due to fungal and invertebrate activity that produce fine and dissolved particles, and physical abrasion caused by current and transported sediment (Ferreira et al., 2006). The effect of these fragmentation types is responsible for leaf tissue breakdown that result in changes of leaf chemical composition and faster decomposition (Ferreira et al., 2006; Santos Fonseca et al., 2013).

Leaf chemical characteristics known to increase breakdown rates and nutritional quality of leaves for invertebrates in streams included high $\mathrm{N}$ and $\mathrm{P}$ (Ardón et al., 2009), low C:N ratio (Enríquez et al., 1993), secondary compounds (Hepp et al., 2009) and lignin content (Ardón et al., 2009). In contrast to the existing information from temperate streams, high diversity of tree species in the tropical riparian vegetation has prompted suggestions that leaf quality plays a more important role on decomposition than in temperate streams (Wantzen et al., 2008). Thus, assesses of the subsequent changes in leaf litter chemistry during breakdown is ecologically essential to understand the dynamics of energy and nutrients in the ecosystem.

We examined chemical changes and invertebrate colonization of leaves from tree species with contrasting chemistry during breakdown in a subtropical stream. Our hypothesis was that changes in the chemistry of leaves during breakdown affects leaf associated invertebrates. We expect that chemical changes of leaf litter (e.g. nutrients, tannins and metals) during breakdown would be related to invertebrates.

\section{Material and Methods}

\subsection{Study area}

The study was conducted in a second-order stream of the Suzana River basin, Southern Brazil

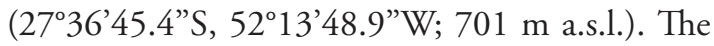
area has a subtropical regional climate, a mean annual temperature of $17.6^{\circ} \mathrm{C}$, a mean annual precipitation of $1,912 \mathrm{~mm}$ and no dry season. The vegetation is characterized by a mix of Araucaria Forest and Subtropical Atlantic Forest (OliveiraFilho et al., 2013). The riparian trees bordering the stream included Araucaria angustifolia (Bertol.) Kuntze, Ocotea puberula (Rich.) Nees, Cabraela canjerana (Vell.) Mart., Nectandra megapotamica (Spreng) Mez., Sebastiania brasiliensis Spreng. and Campomanesia xanthocarpa O. Berg.

The study stream was nearly $2 \mathrm{~m}$ wide and $0.3 \mathrm{~m}$ deep. During the experimental period, the mean water temperature $( \pm S \mathrm{SD})$ was $20\left( \pm 1^{\circ} \mathrm{C}\right)$. The water had low conductivity $\left(62 \pm 1 \mu \mathrm{S} \mathrm{cm}^{-1}\right)$ and was circumneutral $(\mathrm{pH} 7.6 \pm 0.5)$ and well oxygenated $\left(9 \pm 1 \mathrm{mg} \mathrm{O}_{2} \mathrm{~L}^{-1}, n=4\right)$. The stream has a turbidity of $7 \pm 0.5 \mathrm{NTU}$ and alkalinity of $18 \pm 2 \mathrm{mg} \mathrm{CaCO}_{3} \mathrm{~L}^{-1}$. Moreover, the stream water has $13 \pm 0 \mu \mathrm{g} \mathrm{NH}_{4} \mathrm{~L}^{-1}$ and $0.08 \pm 0.01 \mathrm{mg} \mathrm{PO}_{4} \mathrm{~L}^{-1}$ $(n=2)$. The average current velocity across sampling dates was $0.7 \pm 0.1 \mathrm{~m} \mathrm{~s}^{-1}(n=4)$.

\subsection{Experimental design and leaf litter decomposition}

We used leaves of two native tree of Brazilian Atlantic Forest: Sebastiania brasiliensis Spreng. (Euphorbiaceae) and Campomanesia xanthocarpa O.Berg (Myrtaceae), because these leaves offer contrasting characteristics (for chemical details, Biasi et al., 2013). The leaves of $S$. brasiliensis are thin and soft, with a low $\mathrm{C}: \mathrm{N}$ ratio $(<17)$, whereas those of $C$. xanthocarpa are thick and tough, with a high C:N ratio (> 20). Freshly fallen leaves were collected from the ground under a group of trees near the experimental site in spring 2009 and air-dried.

The leaves were placed in single-species litter bags of $15 \times 20 \mathrm{~cm}$ (10 mm mesh size) and incubated in the stream between November and December 2009. We prepared 32 litter bags (16 litter bags of each species), each containing $2.5 \pm 0.1 \mathrm{~g}$ of air-dried 
leaves. The bags were fixed in place with the help of iron bars and incubated under similar conditions of turbulence and water flow.

Four replicate samples of each leaf species were randomly withdrawn after 3, 7, 14 and 22 days. The retrieved litter bags were enclosed in individual plastic bags and taken to the laboratory. The leaf material was washed over $250 \mu \mathrm{m}$ sieves, then dried in an oven $\left(60^{\circ} \mathrm{C} / 72 \mathrm{~h}\right)$ and weighed to determine leaf dry mass (leaf DM) and for subsequent chemical analysis. In addition, four replicate samples per species were prepared on day 0 for assessment of mass loss in preparation, handling and transport. Moreover, those replicates were used for determination of initial chemical composition. The invertebrates retained on the sieves were preserved in $70 \%$ ethanol and sorted. They were identified to family level with a stereomicroscope and taxonomic keys (Fernández and Domínguez, 2001; Mugnai et al., 2010; Pes et al., 2005).

\subsection{Leaf chemistry}

We determined the chemical composition of decomposing leaves analysing the content of nitrogen, phosphorus, $\mathrm{C}: \mathrm{N}$, polyphenols, tannins, calcium, potassium, and magnesium over the experimental period. All determinations were done on four replicate samples.

The dry leaves were ground in knife mills of $1 \mathrm{~mm}$ mesh for chemical analyses. Samples of powdered dry leaves were used to determine total nitrogen concentration by the Kjeldahl method (Flindt and Lillebø, 2005), total phosphorus after acid digestion $(\mathrm{HCl})$ followed by reaction with ascorbic acid (Flindt and Lillebø, 2005) and tannins with the Folin-Ciocalteu method (Bärlocher and Graça, 2005). Samples of dry powder were used to obtain ash-free dry mass (AFDM) by gravimetry after incineration at $550^{\circ} \mathrm{C}$ for 4 hours. Part of the inorganic material resulting from incineration was diluted with $\mathrm{HNO}_{3}\left(1 \mathrm{~mol} \mathrm{~L}{ }^{-1}\right)$ and the resulting solution was analysed with atomic absorption spectrophotometry to quantify the calcium, potassium and magnesium concentrations. Leaf carbon was estimated as $0.47 \times \mathrm{AFDM}$ (Westlake, 1963).

\subsection{Data analysis}

We estimated litter breakdown rates $\left(k\right.$ day $\left.^{-1}\right)$ of the tree species by linear regressions of percentage mass (ln transformed) over time to facilitate comparison of decomposition process of leaves between studies done in different locations and with different species of leaves. The initial chemistry of leaves was compared using Student's $t$-tests. The relationship between density of invertebrates ( $\log x+1$-transformed data) and chemical compounds of leaves was examined by multiple linear regression analysis (stepwise method, excluding non-significant variables at $\mathrm{P}>0.05$; Logan, 2010a). We assessed the chemical changes of leaves and the variability of density of each functional feeding group during breakdown by twoway analysis of variance. We used the incubation time as a proxy for temporal changes of leaves and the interaction of time and leaves as different temporal dynamic between two tree species of leaves (Logan, 2010b). The response variables were $\log (x+1)$-transformed prior analysis of variance to normalised the data and reduced the difference in the variance. All analyses were run using the $\mathrm{R}$ software (R Core Team, 2013).

\section{Results}

The density of invertebrates was related to the chemical composition of leaves $\left(\mathrm{F}_{5,26}=42.85\right.$; $P<0.001)$. The multiple regression model revealed a positive correlation of $K$ and a negative correlation of the C: $\mathrm{N}$ ratio, total polyphenols, $\mathrm{Ca}$ and $\mathrm{Mg}$ with the invertebrate density (Table 1). Leaf chemistry varied widely over the experimental period (Figure 1, Table 2). N on leaves increased over time, while $\mathrm{P}$ decreases until $14^{\text {th }}$ day increasing after this. Tannins, polyphenols and the metals $\mathrm{K}$ and $\mathrm{Mg}$ followed similar dynamics with fast leaching of leaves. The C: $\mathrm{N}$ ratio followed the opposed $\mathrm{N}$ patterns, while $\mathrm{Ca}$ concentration fluctuated during incubation time.

After 22 days of incubation, the leaves of $S$. brasiliensis lost an average of $77 \% \pm 6$ SD of their initial AFDM, while C. xanthocarpa lost an average of $41 \% \pm 8$. The leaf breakdown were relatively high for both species $\left(k=-0.0640 \mathrm{day}^{-1}\right.$ and $k=-0.0219$ day $^{-1}$, respectively).

Table 1. Summary of final multiple regression model to test for correlation ( $\beta$ ) between concentrations of chemical compounds of leaves and density of associated invertebrates during leaf breakdown.

\begin{tabular}{lrr}
\hline \multicolumn{1}{c}{ Chemical compounds } & $\beta$ & $\boldsymbol{P}$-value \\
\hline Nitrogen & -0.93 & 0.719 \\
Phosphorus & 1.78 & 0.397 \\
C:N & -0.34 & $\mathbf{0 . 0 4 8}$ \\
Polyphenols & -0.16 & $<\mathbf{0 . 0 0 1}$ \\
Tannins & -0.11 & 0.340 \\
Magnesium & -2.58 & $<\mathbf{0 . 0 0 1}$ \\
Potassium & 3.48 & $<\mathbf{0 . 0 0 1}$ \\
Calcium & -2.98 & $\mathbf{0 . 0 0 1}$ \\
\hline
\end{tabular}



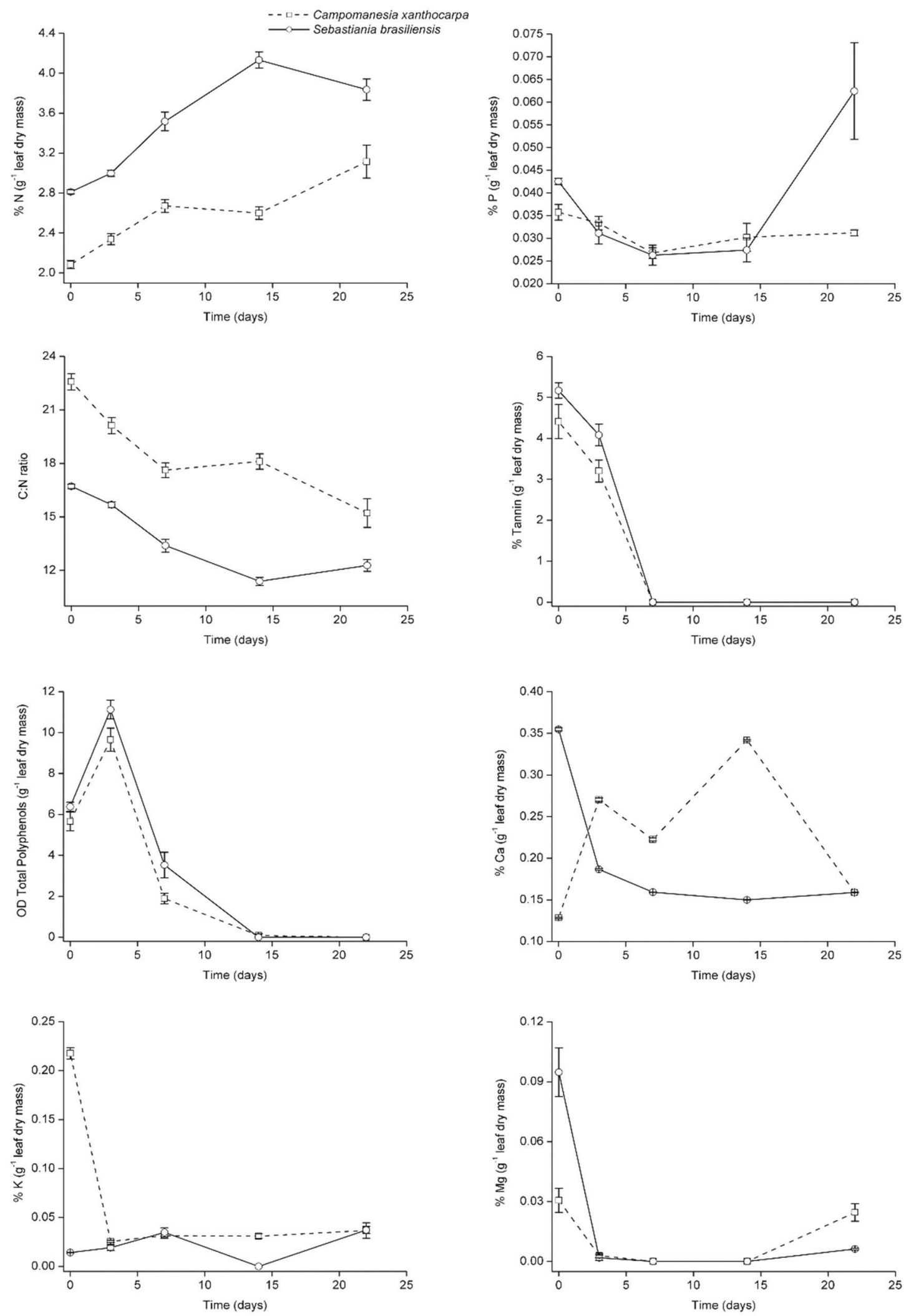

Figure 1. Temporal variations of chemical compounds of leaves of tree species in a subtropical stream. $\mathrm{OD}=$ optical density. 
We collected 7245 organisms, classified into 17 families. The Chironomidae (Diptera) was the most abundant family, with $71.91 \%$ of all organisms collected. The family Simuliidae (Diptera) was the second most abundant, with $20.11 \%$ of the total organisms. These two taxa represented approximately $92 \%$ of the invertebrates associated with the leaf litter (Table 3). Density of invertebrates

Table 2. Summary for two-way ANOVAs results to test for changes in concentration of leaf chemical compounds and the density of each functional feeding group during breakdown.

\begin{tabular}{lrrrr}
\hline & \multicolumn{2}{c}{ Incubation time } & \multicolumn{2}{c}{ Leaves $\times$ incubation time } \\
\hline \multicolumn{1}{c}{ Chemical compounds } & $F$-value & $\boldsymbol{P}$-value & \multicolumn{1}{c}{$\boldsymbol{F}$-value } & $\boldsymbol{P}$-value \\
\hline Nitrogen & $F_{3,24}$ & & $F_{3,24}$ & $<\mathbf{0 . 0 0 1}$ \\
Phosphorus & 32.5 & $<\mathbf{0 . 0 0 1}$ & 8.3 & $\mathbf{0 . 0 0 1}$ \\
C:N & 9.3 & $<\mathbf{0 . 0 0 1}$ & 7.6 & $\mathbf{0 . 0 0 1}$ \\
Tannins & 32.7 & $<\mathbf{0 . 0 0 1}$ & $\mathbf{0 . 0 0 6}$ \\
Polyphenols & 1324.4 & $<\mathbf{0 . 0 0 1}$ & 5.3 & $\mathbf{0 . 0 0 7}$ \\
Magnesium & 561.0 & $<\mathbf{0 . 0 0 1}$ & 5.1 & $\mathbf{0 . 0 0 1}$ \\
Potassium & 40.1 & $<\mathbf{0 . 0 0 1}$ & 14.7 & $\mathbf{0 . 0 0 1}$ \\
Calcium & 13.7 & $<\mathbf{0 . 0 0 1}$ & 8.6 & $\mathbf{0 . 0 0 1}$ \\
\hline Functional feeding groups & 2504.0 & $<\mathbf{0 . 0 0 1}$ & 2616.2 & 0.83 \\
\hline Gathering-collectors & $F_{3,24}$ & & $F_{3,24}$ & 0.44 \\
Filtering-collectors & 4.6 & $\mathbf{0 . 0 1 1}$ & 0.9 & 0.34 \\
Predators & 8.8 & $<\mathbf{0 . 0 0 1}$ & 1.2 & 0.87 \\
Shredders & 13.1 & $<\mathbf{0 . 0 0 1}$ & 0.2 & 0.64 \\
Scrapers & 1.8 & 0.17 & 0.6 & 0.69 \\
Chironomids & 2.4 & $\mathbf{0 . 0 9 3}$ & 0.5 & $\mathbf{0 . 0 0 1}$ \\
\hline
\end{tabular}

Table 3. Means \pm SE combined over time of densities (individuals $\mathrm{g}^{-1}$ leaf dry mass), relative abundance (\%) and corresponding Feeding Functional Group (FFG) of total invertebrates associated on leaves of tree species in a subtropical stream ."-” = FFG not assigned, GC = gathering-collectors, FC = filtering-collectors, P = predators, Sc = scrapers, $\mathrm{Sh}=$ shredders .

\begin{tabular}{|c|c|c|c|c|c|}
\hline \multirow{2}{*}{ Taxa } & \multicolumn{2}{|c|}{ C. xanthocarpa } & \multicolumn{2}{|c|}{ S. brasiliensis } & \multirow{2}{*}{ FFG } \\
\hline & Density & Abundance & Density & Abundance & \\
\hline \multicolumn{6}{|l|}{ COLEOPTERA } \\
\hline Elmidae & $0.1 \pm 0.0$ & 0.03 & $1 \pm 0.4$ & 0.09 & $\mathrm{GC} / \mathrm{Sc}$ \\
\hline Gyrinidae & 0 & 0 & $0.3 \pm 0.1$ & 0.02 & $\mathrm{P}$ \\
\hline \multicolumn{6}{|l|}{ DIPTERA } \\
\hline Chironomidae & $303 \pm 60.8$ & 71.91 & $638 \pm 120.9$ & 75.05 & - \\
\hline Ceratopogonidae & 0 & 0 & $0.2 \pm 0.0$ & 0.02 & $\mathrm{P}$ \\
\hline Empididae & 0 & 0 & $0.6 \pm 0.3$ & 0.05 & $\mathrm{P}$ \\
\hline Simuliidae & $75 \pm 17.6$ & 20.11 & $120 \pm 12.9$ & 17.05 & $\mathrm{FC}$ \\
\hline Psychodidae & 0 & 0 & $0.2 \pm 0.0$ & 0.02 & $\mathrm{GC}$ \\
\hline \multicolumn{6}{|c|}{ EPHEMEROPTERA } \\
\hline Baetidae & $21 \pm 1.8$ & 5.21 & $36 \pm 4.1$ & 4.72 & $\mathrm{GC} / \mathrm{Sc}$ \\
\hline Caenidae & $6 \pm 1.7$ & 0.49 & $8 \pm 1.6$ & 0.83 & GC \\
\hline Leptophlebiidae & $1 \pm 0.4$ & 0.26 & $2 \pm 0.1$ & 0.21 & $\mathrm{GC} / \mathrm{Sc}$ \\
\hline \multicolumn{6}{|l|}{ ODONATA } \\
\hline Coenagrionidae & $0.1 \pm 0.0$ & 0.03 & 0 & 0 & $\mathrm{P}$ \\
\hline Calopterygidae & $0.1 \pm 0.0$ & 0.03 & $0.1 \pm 0.0$ & 0.02 & $\mathrm{P}$ \\
\hline \multicolumn{6}{|l|}{ PLECOPTERA } \\
\hline Grypopterigidae & $0.2 \pm 0.1$ & 0.07 & $1 \pm 0.2$ & 0.14 & Sh \\
\hline \multicolumn{6}{|l|}{ TRICHOPTERA } \\
\hline Calamoceratidae & $1 \pm 0.2$ & 0.16 & 0 & 0 & Sh \\
\hline Hydropsychidae & $7 \pm 1.7$ & 1.65 & $18 \pm 5.9$ & 1.61 & FC/P \\
\hline Leptoceridae & 0 & 0 & $0.4 \pm 0.2$ & 0.05 & $\mathrm{GC} / \mathrm{Sh} / \mathrm{P}$ \\
\hline Odontoceridae & $0.1 \pm 0.0$ & 0.03 & $0.3 \pm 0.1$ & 0.05 & Sh \\
\hline Unknown & 0 & 0 & $0.2 \pm 0.1$ & 0.05 & - \\
\hline Total Density & $414.5 \pm 64$ & & $825.2 \pm 134$ & & \\
\hline
\end{tabular}


on leaves reached $38 \pm 9$ and $192 \pm 31$ individuals $\mathrm{g}^{-1}$ leaf DM (mean of density in both leaf species \pm SE) during the first 3 and 7 days of incubation, had decreased by the 14 th day $\left(117 \pm 18\right.$ individuals $\mathrm{g}^{-1}$ leaf DM) and then increased, reaching $270 \pm 41$ individuals $\mathrm{g}^{-1}$ leaf DM after 22 days (Figure 2). In terms of trophic groups, scrapers and gatheringcollectors densities increased over time, reaching highest values on 14-22 days. Densities of filteringcollectors were higher in intermediate incubation times (7-14 days), while predators and chironomids reach highest densities in final period of incubation (22 day; Figure 3).

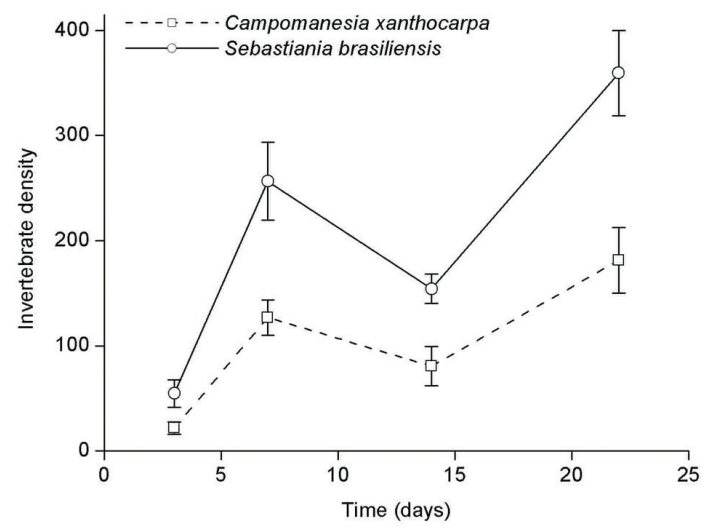

Figure 3. Percentage of functional feeding groups (excluding chironomids for functional feeding classification) of invertebrate community on leaves of tree species during breakdown of C. xanthocarpa a) and S. brasiliensis b) leaves in a subtropical stream.

\section{Discussion}

The invertebrate density was correlated with the chemistry of leaves during breakdown. The negative correlation of polyphenols and invertebrate densities may be due to progress of breakdown that leached this compound and elevated the nutritional quality of leaves to invertebrates. Furthermore, we suggest that the ions $(\mathrm{K}, \mathrm{Mg}$ and $\mathrm{Ca}$ ) were only correlated with the density of invertebrates due to its rapid leached ( $\mathrm{K}$ and $\mathrm{Mg}$ ) or oscillation $(\mathrm{Ca})$ from leaves. Leaves of $S$. brasiliensis exhibited the fastest breakdown, lower $\mathrm{C}: \mathrm{N}$ ratio and consequently the greatest density of invertebrates over time. Mathuriau and Chauvet (2002) found a similar pattern in a tropical stream where softer texture and lower C:N leaves breakdown more rapidly and supported higher densities of invertebrates.

The leaching of soluble compounds was responsible for the initial mass loss of leaves (Gonçalves et al., 2006; Hepp et al., 2008). The relatively high water temperatures and water flow in the stream can potentially accelerate the decomposition through physical or biological effects on the leaf litter (Ferreira et al., 2006; Irons III et al., 1994). The difference in breakdown rates between tree species were partly explained by the high $\mathrm{N}$ and $\mathrm{P}$ contents in $\mathrm{S}$. brasiliensis leaves (Richardson et al., 2004; Shieh et al., 2008). The N content in $S$. brasiliensis leaves is among the highest found in 53 temperate tree species by Flindt and Lillebø (2005) and in 8 tropical tree species analysed by Ardón et al. (2009). Leaves of C. xanthocarpa (a)

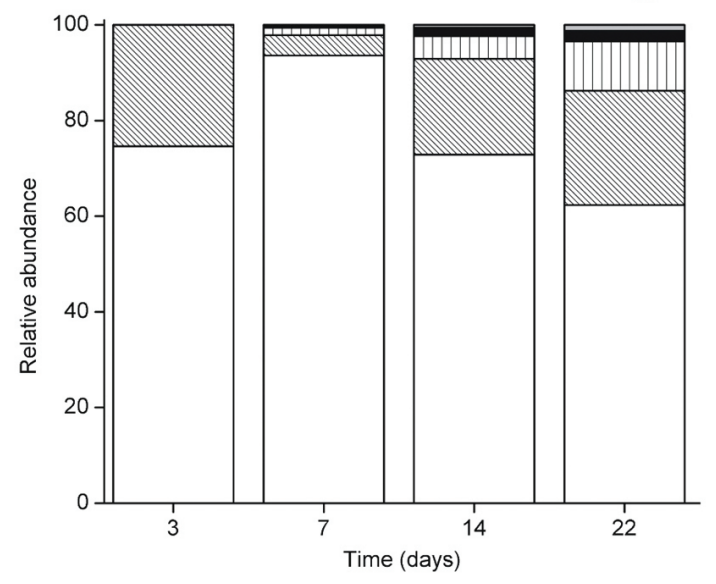

(b)

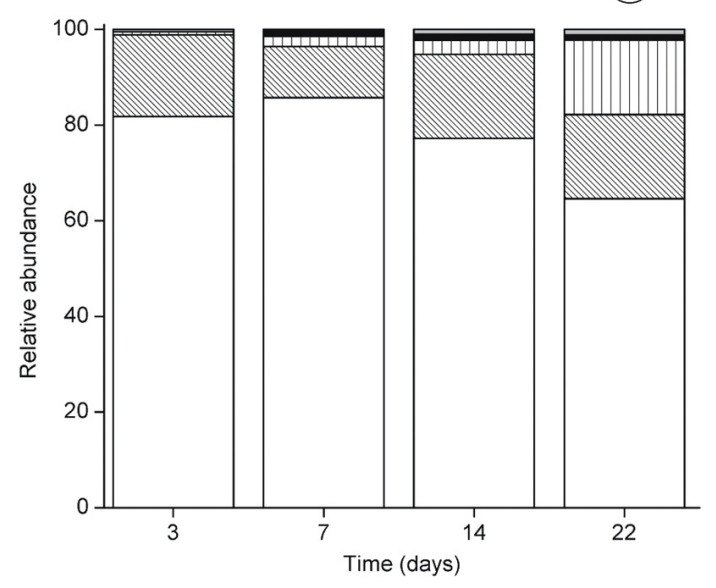

$\square$ Filtering-Collectors $\amalg$ Gathering-Colletors $\square$ Predators $\square$ Shredders $\square$ Scrapers

Figure 2. Temporal variations in invertebrate density individuals per gram of ash free dry mass [AFDM]; mean \pm SE) on leaves of tree species in a subtropical stream. 
had an intermediate concentration of this nutrient. We hypothesised that the increase in leaf $\mathrm{N}$ concentration is due to microbial conditioning of leaves through time (Graça et al., 2001). This increase leads to an increment in nutritional quality and the attractiveness of the detritus for invertebrates (Mathuriau and Chauvet, 2002).

Secondary compounds (i.e., total polyphenols and tannins) were rapidly leached at rates four times greater than the rates reported for temperate leaves by Bärlocher et al. (1995) and for tropical leaves by Ardón and Pringle (2008). Both species lost more than $50 \%$ of their secondary compounds during the first week of incubation in the stream. Previous studies have suggested that high concentrations of these compounds inhibit colonisation by invertebrates, slowing leaf breakdown (Hepp et al., 2009; Stout, 1989; Wantzen et al., 2002). However, the rapid leaching of these leaf compounds may have reduced the inhibitory effect on invertebrates. Our results are in accordance with Ardón and Pringle (2008) and Ardón et al. (2009) who conclude that secondary compounds are rapidly leached, and thus does not play a direct role in leaf breakdown.

The general decrease in the concentrations of metals ( $\mathrm{Ca}, \mathrm{Mg}$ and $\mathrm{K}$ ) in the detritus, especially during the initial period of the incubation, can be related to the breakdown of leaf tissue and the associated loss of soluble compounds. Shieh et al. (2008) observed high release rates of $\mathrm{K}, \mathrm{Mg}$ and $\mathrm{Ca}$ from leaf litter in a subtropical stream and hypothesised that the dissolution of these compounds accelerated leaf degradation.

The decay rates for C. xanthocarpa and $S$. brasiliensis can be considered rapid according to Gonçalves et al. (2013). The decomposition rates obtained are among the highest observed for tropical streams (see Gimenes et al., 2010). The rapid breakdown may be due to intrinsic characteristics of the leaves (e.g., chemical composition and texture), and/or the hydrological and chemical features of the stream (high water flow and nutrients such as $\mathrm{P}$ and $\mathrm{N}$ in water).

Higher densities of filtering and gatheringcollectors in intermediate times of incubation (7 and 14 days) may be explained by the availability of fine particulate organic matter (FPOM) as a food resource, mainly in leaves that decompose rapidly ( $S$. brasiliensis). The two rainfall events over the experimental period increased the water flow and may have intensified the release of FPOM to the water column. Furthermore, collectors may be using leaf detritus as substrate to cling to
(Dudgeon and Wu, 1999), certainly in the early stages of the experiment when FPOM is most likely from an outside source. Wantzen et al. (2006) expected a reduction in leaf-feeding specialist and an increase in organisms with generalized and opportunistic feeding strategies where frequent spates interfere with biological degradation (e.g., some tropical streams). This increase is evident for collectors, particularly for chironomids, that dominate the food webs of small tropical streams (Rueda-Delgado et al., 2006). Despite chironomids dominance, their role on leaf breakdown is uncertainly, especially considering the low density of shredder or miner chironomids in the community (Biasi et al., 2013; Landeiro et al., 2008).

We observed a low density of invertebrate shredders in relation to other functional groups. This trophic group have a key factor in low-order stream ecosystems because they feed organic detritus and shred into small particles, providing other forms of C for stream food webs (Graça, 2001; Wallace et al., 1982). The low percentage of shredder invertebrates were observed in some tropical streams (Gonçalves et al., 2007; Moretti et al., 2007; Moulton et al., 2010), suggesting that their occurrence were more variability in these systems (but see Cheshire et al., 2005; Tonin et al., 2014). Furthermore, the density of shredders tended to increase over time as the leaf litter started to breakdown. This tendency may be due to increased nutritional quality of leaf detritus over time ( $\mathrm{N}$ and $\mathrm{P}$ content, and C:N ratio).

We conclude that changes in the chemistry of decomposing leaves affect invertebrate colonization process. We also conclude that leaves become more attractive as a food source to invertebrates through time. These conclusions reinforce the importance in follow leaf litter chemistry over time, especially in tropical streams where the dynamic of organic matter breakdown is poorly studied.

\section{Acknowledgements}

We are grateful to Thomas Tomazoni (Universidade Regional Integrada do Alto Uruguai e das Missóes - Campus Erechim, Brazil) for the identification of leaf tree species. We are grateful to Joseline Molozzi (Universidade Estadual da Paraíba, Brazil), Jean Budke (Universidade Regional Integrada do Alto Uruguai e das Missóes - Campus de Erechim, Brazil), Verónica Ferreira (IMAR - Universidade de Coimbra, Portugal) and José Francisco Gonçalves Jr. (Universidade de Brasília, Brazil) for comments on an early version of the manuscript. AMT received a 
scholarship from Universidade Regional Integrada do Alto Uruguai e das Missóes - Campus Erechim. RMR received financial support from $\mathrm{CNPq}$ (Process \#475251/2009-1).

\section{References}

ARDÓN, M. and PRINGLE, CM. 2008. Do secondary compounds inhibit microbial- and insect-mediated leaf breakdown in a tropical rainforest stream, Costa Rica? Oecologia, vol. 155, no. 2, p. 311 323. PMid:18049828. http://dx.doi.org/10.1007/ s00442-007-0913-x

ARDÓN, M., PRINGLE, CM. and EGGERT, SL. 2009. Does leaf chemistry differentially affect breakdown in tropical vs temperate streams? Importance of standardized analytical techniques to measure leaf chemistry. Journal of the North American Benthological Society, vol. 28, no. 2, p. 440-453. http://dx.doi. org/10.1899/07-083.1

BÄRLOCHER, F., CANHOTO, C. and GRAÇA, MAS. 1995. Fungal colonization of alder and eucalypt leaves in two streams in Central Portugal. Archiv für Hydrobiologie, vol. 133, no. 4, p. 457-470.

BÄRLOCHER, F. and GRAÇA, MS. 2005. Total Phenolics. In GRAÇA, MAS., BÄRLOCHER, F. and GESSNER, MO., org. Methods to study litter decomposition. Netherlands: Springer. p. 97-100.

BIASI, C., TONIN, AM., RESTELLO, RM. and HEPP, LU. 2013. The colonisation of leaf litter by Chironomidae (Diptera): The influence of chemical quality and exposure duration in a subtropical stream. Limnologica - Ecology and Management of Inland Waters, vol. 43, no. 6, p. 427-433.

CHESHIRE, K., BOYERO, L. and PEARSON, RG. 2005. Food webs in tropical Australian streams: shredders are not scarce. Freshwater Biology, vol. 50, no. 5, p. 748-769. http://dx.doi.org/10.1111/j.13652427.2005.01355.x

DUDGEON, D. and WU, KK. 1999. Leaf litter in a tropical stream: food or substrate for macroinvertebrates? Archiv für Hydrobiologie, vol. 146, no. 1, p. 65-82.

ENRÍQUEZ, S., DUARTE, CM. and SAND-JENSEN, K. 1993. Patterns in decomposition rates among photosynthetic organisms: the importance of detritus C:N:P content. Oecologia, vol. 94, no. 4, p. 457-471. http://dx.doi.org/10.1007/BF00566960

FERNÁNDEZ, HR. and DOMÍNGUEZ, E. 2001. Guía para la determinación de los artrópodos bentónicos sudamericanos. Tucumán: Editorial Universitaria de Tucumán.

FERREIRA, V., GRAÇA, MAS., LIMA, JLMP. and GOMES, R. 2006. Role of physical fragmentation and invertebrate activity in the breakdown rate of leaves. Archiv für Hydrobiologie, vol. 165, no. 4, p. 493-513. http://dx.doi.org/10.1127/00039136/2006/0165-0493

FLINDT, MR. and LILLEBØ, AI. 2005. Determination of total nitrogen and phosphorus in leaf litter. In GRAÇA, MAS., BÄRLOCHER, F. and GESSNER, MO., org. Methods to study litter decomposition. Netherlands: Springer. p. 53-59.

GIMENES, KZ., CUNHA-SANTINO, MB. and BIANCHINI JUNIOR, I. 2010. Decomposição de matéria orgânica alóctone e autóctone em ecossistemas aquáticos. Oecologia Australis, vol. 14, no. 4, p. 1036-1073. http://dx.doi.org/10.4257/ oeco.2010.1404.13

GONÇALVES, JF., FRANÇA, JS., MEDEIROS, AO., ROSA, CA. and CALLISTO, M. 2006. Leaf breakdown in a tropical stream. International Review of Hydrobiology, vol. 91, no. 2, p. 164-177. http:// dx.doi.org/10.1002/iroh.200510826

GONÇALVES, JFJ., GRAÇA, MAS. and CALLISTO, M. 2007. Litter decomposition in a Cerrado savannah stream is retarded by leaf toughness, low dissolved nutrients and a low density of shredders. Freshwater Biology, vol. 52, no. 8, p. 1440-1451. http://dx.doi. org/10.1111/j.1365-2427.2007.01769.x

GONÇALVES, JFJ., MARTINS, R., OTTONI, BMP. and COUCEIRO, SRM. 2013. Uma visão sobre a decomposição foliar em sistemas aquáticos brasileiros. In HAMADA, N., NESSIMIAN, JL. and QUERINO, RB., org. Insetos aquáticos: biologia, ecologia e taxonomia. Manaus: Editora do INPA.

GONÇALVES, JFJ., REZENDE, RS., MARTINS, NM. and GREGORIO, RS. 2012. Leaf breakdown in an Atlantic Rain Forest stream. Austral Ecology, vol. 37, no. 7, p. 807-815. http://dx.doi.org/10.1111/j.14429993.2011.02341.x

GRAÇA, MAS. 2001. The role of invertebrates on leaf litter decomposition in streams: a review. International Review of Hydrobiology, vol. 86, no. 4-5, p. 383-393. http://dx.doi. org/10.1002/1522-2632(200107)86:4/5<383::AIDIROH383>3.0.CO;2-D

GRAÇA, MAS., CRESSA, C., GESSNER, MO., FEIO, MJ., CALLIES, KA. and BARRIOS, C. 2001. Food quality, feeding preferences, survival and growth of shredders from temperate and tropical streams. Freshwater Biology, vol. 46, no. 7, p. 947-957. http:// dx.doi.org/10.1046/j.1365-2427.2001.00729.x

HEPP, LU., BIASI, C., MILESI, SV., VEIGA, F. and RESTELLO, RM. 2008. Chironomidae (Diptera) larvae associated to Eucalyptus globulus and Eugenia uniflora leaf litter in a subtropical stream (Rio Grande do Sul, Brazil). Acta Limnologica Brasiliensia, vol. 20, no. 4, p. 345-350.

HEPP, LU., DELANORA, R. and TREVISAN, A. 2009. Compostos secundários durante a decomposiçáo foliar de espécies arbóreas em um riacho do sul 
do Brasil. Acta Botanica Brasilica, vol. 23, no. 2, p. 407-413. http://dx.doi.org/10.1590/S010233062009000200012

HIEBER, M. and GESSNER, MO. 2002. Contribution of stream detrivores, fungi, and bacteria to leaf breakdown based on biomass estimates. Ecology, vol. 83, no. 4, p. 1026-1038. http://dx.doi. org/10.1890/0012-9658(2002)083[1026:COSDF A]2.0.CO;2

IRONS III, JG., OSWOOD, MW., STOUT, RJ. and PRINGLE, CM. 1994. Latitudinal patterns in leaf litter breakdown: is temperature really important? Freshwater Biology, vol. 32, no. 2, p. 401-411. http:// dx.doi.org/10.1111/j.1365-2427.1994.tb01135.x

LANDEIRO, VL., HAMADA, N. and MELO, AS. 2008. Responses of aquatic invertebrate assemblages and leaf breakdown to macroconsumer exclusion in Amazonian "terra firme" streams. Fundamental and Applied Limnology, vol. 172, no. 1, p. 49-58. http:// dx.doi.org/10.1127/1863-9135/2008/0172-0049

LOGAN, M. 2010a. Multiple and curvilinear regression. In LOGAN, M., org. biostatistical design and analysis using $R$ : a practical guide. Oxford: Wiley-Blackwell. p. 208-253. http://dx.doi. org/10.1002/9781444319620.ch9

LOGAN, M. 2010b. Factorial ANOVA. LOGAN, M., org. Biostatistical design and analysis using $R$ : a practical guide. Oxford: Wiley-Blackwell. p. 313359. http://dx.doi.org/10.1002/9781444319620. ch12

MATHURIAU, C. and CHAUVET, E. 2002. Breakdown of leaf litter in a neotropical stream. Journal of the North American Benthological Society, vol. 21, no. 3, p. 384-396. http://dx.doi.org/10.2307/1468477

MORETTI, MS., GONÇALVES, JF., LIGEIRO, R. and CALLISTO, M. 2007. Invertebrates Colonization on Native Tree Leaves in a Neotropical Stream (Brazil). International Review of Hydrobiology, vol. 92, no. 2, p. 199-210. http://dx.doi.org/10.1002/ iroh.200510957

MOULTON, T., MAGALHÃES-FRAGA, SP., BRITO, E. and BARBOSA, F. 2010. Macroconsumers are more important than specialist macroinvertebrate shredders in leaf processing in urban forest streams of Rio de Janeiro, Brazil. Hydrobiologia, vol. 638, no. 1, p. 55-66.

MUGNAI, R., NESSIMIAN, JL. and BAPTISTA, DF. 2010. Manual de identificação de Macroinvertebrados aquáticos do Estado do Rio de Janeiro. Rio de Janeiro: Techinal Books.

OLIVEIRA-FILHO, AT., BUDKE, JC., JARENKOW, JA., EISENLOHR, PV. and NEVES, DRM. 2013. Delving into the variations in tree species composition and richness across South American subtropical Atlantic and Pampean forests. Journal of Plant Ecology. In press.
PES, AMO., HAMADA, N. and NESSIMIAN, JL. 2005. Chaves de identificação de larvas para famílias e gêneros de Trichoptera (Insecta) da Amazônia Central, Brasil. Revista Brasileira de Entomologia, vol. 49, no. 2, p. 181-204. http://dx.doi.org/10.1590/ S0085-56262005000200002

RICHARDSON, JS., SHAUGHNESSY, CR. and HARRISON, PG. 2004. Litter breakdown and invertebrate association with three types of leaves in a temperate rainforest stream. Archiv für Hydrobiologie, vol. 159, no. 3, p. 309-325.

RUEDA-DELGADO, G., WANTZEN, KM. and TOLOSA, MB. 2006. Leaf-litter decomposition in an Amazonian floodplain stream: effects of seasonal hydrological changes. Journal of the North American Benthological Society, vol. 25, no. 1, p. 233-249. http:// dx.doi.org/10.1899/0887-3593(2006)25[233:LDIA $\mathrm{AF}] 2.0 . \mathrm{CO} ; 2$

SANTOS FONSECA, A., BIANCHINI JUNIOR, I., PIMENTA, C., SOARES, C. and MANGIAVACCHI, N. 2013. The flow velocity as driving force for decomposition of leaves and twigs. Hydrobiologia, vol. 703, no. 1, p. 59-67. http://dx.doi.org/10.1007/ s10750-012-1342-3

SHIEH, S-H., WANG, C-P., HSU, C-B. and YANG, P-S. 2008. Leaf breakdown in a subtropical stream: nutrient release patterns. Fundamental and Applied Limnology/Archiv für Hydrobiologie, vol. 171, no. 4, p. 273-284.

STOUT, RJ. 1989. Effects of condensed tannins on leaf processing in mid-latitude and tropical streams: a theoretical approach. Canadian Journal of Fisheries and Aquatic Sciences, vol. 46, no. 7, p. 1097-1106. http://dx.doi.org/10.1139/f89-142

TONIN, AM., HEPP, LU., RESTELLO, RM. and GONÇALVES JUNIOR, JF. 2014, Understanding of colonization and breakdown of leaves by invertebrates in a tropical stream is enhanced by using biomass as well as count data. Hydrobiologia. In press.

WALLACE, JB. 1997. Multiple trophic levels of a forest stream linked to terrestrial litter inputs. Science, vol. 277, no. 5322, p. 102-104. http://dx.doi. org/10.1126/science.277.5322.102

WALLACE, JB., WEBSTER, J. and CUFFNEY, T. 1982. Stream detritus dynamics: Regulation by invertebrate consumers. Oecologia, vol. 53, no. 2, p. 197-200. http://dx.doi.org/10.1007/BF00545663

WANTZEN, K., WAGNER, R., SUETFELD, R. and JUNK, W. 2002. How do plant-herbivore interactions of trees influence coarse detritus processing by shredders in aquatic ecosystems of different latitudes? Internationale Vereinigung fur Theoretische und Angewandte Limnologie Verhandlungen, vol. 28, no. 2, p. 815-821. http://dx.doi.org/10.1002/aqc.807

WANTZEN, KM., SIQUEIRA, A., CUNHA, CN. and PEREIRA DE SÁ, MF. 2006. Stream-valley systems 
of the Brazilian Cerrado: impact assessment and conservation scheme. Aquatic Conservation: Marine and Freshwater Ecosystems, vol. 16, no. 7, p. 713-732.

WANTZEN, KM., YULE, CM., MATHOOKO, JM. and PRINGLE, CM. 2008. Organic matter processing in tropical streams. In DUDGEON, D., org. Tropical stream ecology. Amsterdam: Elsevier. p. 43-64.

WESTLAKE, DF. 1963, Comparisons of plant productivity. Biological Reviews, vol. 38, no. 3, p. 385425. http://dx.doi.org/10.1111/j.1469-185X.1963. tb00788.x

Received: 20 January 2014

Accepted: 11 August 2014 